\title{
STUDY ON THE ENERGY OVERVIEW OF THE INDUSTRIAL BEVERAGE SECTOR IN COLOMBIA
}

\author{
ESTUDIO DE PANORAMA \\ ENERGÉTICO DEL SECTOR \\ INDUSTRIAL DE BEBIDAS EN \\ COLOMBIA
}

\author{
Jhan Piero Rojas ${ }^{1}$ \\ Mawency Vergel ${ }^{2}$ \\ 'Sofia Orjuela ${ }^{3}$ \\ Universidad Francisco de Paula Santander, \\ Cúcuta, Colombia Colombia
}

\begin{abstract}
In the Latin American region, the issues of efficiency in energy consumption and clean energy sources become more important every day, and worldwide, these issues are of great importance because a progressive change

$1 \quad$ Facultad de Ingenierías, Universidad Francisco de Paula Santander, Cúcuta, Colombia. Correo jhanpierorojas@ufps.edu.co ORCID iD: https://orcid.org/0000-00032682-9880

2 Departamento de Matemáticas y Estadística, Universidad Francisco de Paula Santander, Norte de Santander, Cúcuta, Colombia, correo: mawencyvergel@ufps.edu.co Orcid: https://orcid.org/0000-0001-8285-2968

$3 \quad$ Facultad de Ciencias Empresariales, Universidad Francisco de Paula Santander, Cúcuta, Colombia. Correo: sofiaorjuela@ufps.edu.co ORCID: https://orcid.org/00000002-9742-8673
\end{abstract}

in the use of energy is required for reasons such as climate change, polluting emissions and forecasting of a shortage of fossil or non-renewable fuel reserves. The Colombian government is no stranger to these issues, and since 2001, energy efficiency plans have been implemented, creating a nationwide program for the proper use of energy sources that seeks, through analysis of the national energy landscape, the implementation of technical and technological actions that improve energy efficiency in all sectors of the country. This paper shows the study made to the industry of (number of companies) in the 
beverage sector, which characterized the use of different types of energy such as natural gas and electric energy and the transformation of these in their processes of production, which seeks to determine how efficiently the potential of energy resources is used. Only in the energy consumption for lighting were savings potentials of up to $50 \%$ detected. It is also shown how, through legislation and studies conducted under the direction of the Energy Mining Planning Unit, the aim is to have a more competitive industrial sector against international markets, specifically taking the industrial sector of beverage production as a sample.

\section{KEYWORDS:}

Consumption Reduction, Energy Efficiency, Industry, Law, Renewable Sources.

\section{INTRODUCTION}

In Colombia, strategies are continuously created (MINMINAS, UPME, 2016) that aim at better use of energy sources and the implementation of clean and renewable energy sources (Pupo-Roncallo, Campillo, Ingham, Hughes, \& Pourkashanian, 2020) (Zapata et al., 2018), anticipating the future shortage of fossil energy sources and leaning on the potential of the available resources as shown (López et al., 2020) (Solaun \& Cerdá, 2019) this thanks to international level initiatives (NU. CEPAL \& CAF, 2013) whose priority is to improve energy efficiency (WEC, 2011). Governments with the creation of policies and strategies applied to the industry to decrease energy consumption and increase its efficiency as a sample (Tanaka, 2011) and it is now the main part of the political agendas of many countries (Bunse, Vodicka, Schönsleben, Brülhart, \& Ernst, 2011).

Not only the improvement in the good use of energy resources and the implementation of energy production through renewable energies
(CEPAL \& GTZ, 2004) (CEPAL \& GTZ, 2003) occur in the investment of resources for the creation of power plants. Energy production based on renewable energies, if not an important factor in this improvement is, how efficiently the energy produced is used, which is the subject of debate (Giacone \& Mancò, 2012) and (Flum, Abele, \& Reidel, 2018), since in Colombia the investment necessary to improve energy efficiency for 2018 is 730 million dollars, but the investment necessary to maintain energy demand for the same date would be 2.3 billion dollars (PRIAS, 2010) In other words, it could be more expensive to maintain demand without improving efficiency.

Said this from the economic point of view, it is crucial to evaluate the energy efficiencies in the industries as analyzed by (Campos I, Nieto, Del Portillo-Valdes, Manzanedo, \& Gaztaña, 2020) (Bermeo \& Ocampo-Martinez, 2019) that could have saved in consumption of up to $50 \%$. In the Nigerian food and beverage industry, it was studied that savings in the consumption of electrical energy of up to $292,436.82 \mathrm{kWh}$ per year could be achieved only by changing lowefficiency electric motors as shown (Ogunjuyigbe, Ayodele, \& Ogunmuyiwa, 2015), on the other hand in some European countries audits were carried out on small and medium industries, which resulted in energy savings of up to $45 \%$ and $\mathrm{CO} 2$ emissions reductions of 30,000 tons, optimizing processes and implementing heat recovery, solar and thermal energy as a sample (Meyers, Schmitt, Chester-Jones, \& Sturm, 2016) (Tzimas, Georgakaki, \& Peteves, 2009).

For countries, this represents a tool with which to achieve energy sustainability developments (Hoffmann, Praß, Uhlemann, \& Franke, 2019) (Zhou, Wang, \& Ou, 2018). In the industries of the European Union, the food and beverage sector consumed $11 \%$ of the final energy demand (Knopf, Nahmmacher, \& Schmid, 2015), as shown by (Fluch, Brunner, \& Grubbauer, 
2017), which highlights that small industries do not have the economic capacity to invest in efficient energy. In Thailand, the industrial sector represents $36.2 \%$ of total energy consumption as says (Chaichaloempreecha, Winyuchakrit, \& Limmeechokchai, 2017), and although its government implements energy efficiency policies, it still has a power of energy saving in small industries as a sample (Wongsapai, Fongsamootr, \& Chaichana, 2017). In the Brazilian government, measures are taken that include the creation of industrial evaluation centers for energy efficiency motivated by the trend of energy saving as a sample (Santana \& Bajay, 2016).

The industrial sector is a major consumer of energy and can consume approximately $37 \%$ of the energy produced worldwide. By 2033 it is found that energy consumption up to $33 \%$ more than world consumption in 2010. For that year, the world energy consumption could reach about 198,654 ZW. China is one of the countries with the highest industrial growth, reaching an energy consumption of $5.5 \%$ per year of world consumption. From another perspective, the industrial sector has great potential for energy use (Abdelaziz, Saidur, \& Mekhilef, 2011). And for this, multiple strategies and policies are carried out to help improve the use of energy resources (Duflou et al., 2012) (Geller, Harrington, Rosenfeld, Tanishima, \& Unander, 2006). Some of the strategies used can be divided into 3 groups: energy audit, energy efficiency training programs, and cleaning service. The latter mainly refers to workspaces, paying more attention to lighting, taking advantage of hours of daylight, and good distribution and maintenance of artificial light. Energy auditing is also used to increase the energy efficiency of companies and are the characterizations of their industrial processes with energy management practices (Thollander \& Ottosson, 2010).
Some actions for the results of the energy audits are the use of heat waste to save directly, such as reducing the cost of public services, fuel consumption, and indirectly, such as reducing environmental pollution, it has been found that saving annual energy using the exhaust gases from a boiler can be 2,529 MWh and can increase the efficiency of the boiler by $2.5-4 \%$. A large part of the electric consumption in the industrial sector is made by electric motors, the replacement of electric motors by old technologies for new and more efficient ones allows the reduction in energy consumption, in Europe changing motorized systems to low consumption motors means a saving of 202 billion $\mathrm{kWh}$ and 79 million tons of $\mathrm{CO} 2$ would no longer be produced (Abdelaziz, Saidur, \& Mekhilef, 2011).

Checking leaks and pressure drops in compressed air systems are other actions that can be taken to reduce consumption and make processes more efficient; up to $50 \%$ of air production is lost in leaks, increase the diameter of the pipes will help reduce losses due to pressure drop and $90 \%$ of the electrical energy consumed by a compressor is converted to heat, so it is convenient to install a heat economizer (Dindorf, 2019) the use of renewable hydrogen, CO2 trapping (Rissman et al., 2020) Energy losses in steam systems as a sample (Chowdhury et al., 2018) and use of waste for generation internal power.

\section{METHOD}

The implementation of international agendas on climate change has raised awareness about the governments of countless countries that today have as their main themes the support from different points of view to environmental issues, creating a technical and legal position against the mitigation of factors that negatively affect climate change. In Colombia, these issues are not alien, and efforts have been taking place in the technical and legal environment regarding 
this. One of the axes on which Colombia addresses this issue is through the efficient use of energy. The industrial sector is one of the sectors that are large consumers of different types of energy and is one of the work sectors on which studies are made to improve its energy efficiency. This not only enables environmental objectives to be met but also allows companies to benefit economically by saving on their industrial processes due to better use of energy resources and making the industry more internationally competitive.

The base legal framework on which many other regulations are built-in Colombian law is given by:

Decree 2119 of 1992, chapter 4, article 12, (Gobierno de Colombia, 1992) creates the Energy Mining Planning Unit (UPME in Spanish) of the Ministry of Mines and Energy, which will function as an administrative and planning unit for the energy mining sector.

Law 143 of 1994 (Gobierno de Colombia, 1994), which expresses in article 2 , the Ministry of Mines and Energy (Spanish Mines) will define the criteria for the use of conventional and unconventional sources of energy, giving comprehensive and sustainable management of these, in addition to promoting the development of sources unconventional and efficient use of existing energy sources.

Decree 1258 of 2013 in article 4 paragraph 10 (Gobierno de Colombia, 2013) that the UPME promote, design and establish plans, programs, and projects related to effective use, energy saving in all sectors of economic activity and that dissemination works are carried out.

Law 697 of 2001 in article 1 (Gobierno de Colombia, 2001) Declares the rational and efficient use of energy (URE in Spanish) as a matter of social, public benefit, and national utility. Indispensable subject with which we can guarantee the good quality of the energy supply, the competition of the Colombian economy, consumer protection, and the spread of the use of unconventional energy friendly to the environment and natural resources.

Law 1715 of 2014 (Congreso de la República de Colombia, 2014) that regulates the integration of non-conventional renewable energy into the National Energy System (SIN in Spanish) and through decrees 2143 of 2015, 1283 of 2016, 1303 of 2018 which regulate and establish the procedures for the application of incentives and certification of environmental benefit for investment in projects of non-conventional sources of non-renewable energy (FNCER in Spanish) and efficient management of the energy respectively.

In UPME resolution 703 of 2018 (UPME, 2018), the requirements and procedures to request the exclusion of VAT and exemption from tariff lien for FNCE projects are established. The tax incentives expressed are: special deduction in the determination of income tax is described in article 11 of law 1715 of 2014 and in decree 2143 of 2015 incorporated into decree 1073 of 2015. Accelerated depreciation, described in article 14 of law 1715 of 2014. Exemption from customs duties, described in article 13 of law 1715 of 2014.

Another important program included in national public policy is the Colombian Low Carbon Development Strategy (ECDBC in Spanish) (Gobierno de Colombia, n.d.), which seeks to decouple national economic growth from growth in greenhouse gas emissions (GHG in Spanish), maximizing carbon efficiency of the country's economic activity.

Resolution 909 of 2008 of the Ministry of Environment, Housing and Territorial Development (Gobierno de Colombia, 2008) establishes standards and parameters of admissible pollutants continuously expelled into 
the atmosphere, which states that for electrical generation equipment of $1 \mathrm{MW}$ or more, they must be no greater than $50 \mathrm{mg} / \mathrm{m}^{3}$ of particulate matter (PM in Spanish), $400 \mathrm{mg} / \mathrm{m}^{3}$ of $\mathrm{SO}_{2}$ and $300 \mathrm{mg} / \mathrm{m}^{3}$ of NOx.

Resolution 018 of 2005 of the Energy and Gas Regulation Commission (CREG in Spanish) (Gobierno Nacional, 2005), which dictates regulations on the flow of reactive power and is responsible for penalizing excess consumption of reactive power of the interconnected System (SIN in Spanish) This penalty determines that consumption of reactive energy greater than $50 \%$ of active energy will be charged as active energy according to the rate.

CREG resolution 029 of 2016 (Gobierno Nacional, 2016) establishes a rating scheme for users of the SIN with which it proposes to promote voluntary savings; these rate schemes promulgate an additional cost per $\mathrm{kWh}$ for users who exceed the established savings goal.

\section{RESULTS AND DISCUSSION}

In Colombia, the industrial sector is the second most important sector of the country's total energy consumption, the first being the transport sector, which is strongly linked to the industrial sector. The industrial sector consumed consuming approximately $30 \%$ of the country's total energy. This sector is divided into subsectors according to their type of production process (MINMINAS, UPME, 2016). The classification is given by the code of International Standard Industrial Classification (ISIC in English) (CIIU in Spanish) of all economic activities, approved by the Economic Council and Social in the Organization at the United Nations (United Nations, 2008) and adopted by the National Administrative Department of Statistics (DANE in Spanish) (DANE, 2020). The industrial sector of beverages corresponds to ISIC 11, which in 2015 had a consumption of 63,061 MWh / year in electrical energy and 222,783 MWh / year of thermal energy (UPME, Colciencias, Incombustion, 2014).

\subsection{STATUS WORLDWIDE}

Global energy consumption is of vital importance, and one of the most energy-consuming sectors worldwide is the industrial sector, with $37 \%$ of total energy consumption worldwide. The United States consumes $25 \%$ of the energy worldwide, but China grows rapidly, increasing $5.5 \%$ per year (U.S. Energy Information Administration, 2019). Energy consumption is expected to grow $1.4 \%$ annually, and by 2030 world consumption will be $71,961 \mathrm{ZW}$. In the USA, $33 \%$ of total energy consumption is found in the industry. In China, $85 \%$ of total energy is consumed by industry, and in India, industry consumes $64 \%$ of total energy.

At an international level, countries have created regulations and standards that allow for increased energy efficiency. In China, the China Standard Certification Center (CSC) is in charge of developing energy management norms and standards for the energy management system (Abdelaziz, Saidur, \& Mekhilef, 2011). In the Netherland, they establish a management system based on ISO standards with the collaboration of Bureau Veritas agreements were signed that have an obligation to implement an efficient management system. In Sweden, it started with a voluntary energy management agreement and then created a program to improve Energy Efficiency in Energy-Intensive Industries (PFE in English) after placing an electricity-related tax.

The implementation of technological advances that occur not only because they seek to mitigate polluting emissions and energy waste but also seek to produce more for less, that is, to maintain production rates for less money invested in the operation, some of the most common solutions for energy saving are the use of variable speed drives, high-efficiency motors, efficient nozzles in compressed air systems and residual heat 
recovery systems in boilers or economizers.

A Variable Speed Drive (VSD) is an electronic control device that allows you to generate a multiphase, variable frequency output that can be used to control the motor's speed, torque, and mechanical power output. This is useful and presents a significant saving since, in most cases, the motors do not work at $100 \%$ of their power. For example, the motors used in pumping fluids; generally, these systems require regulating valves that decrease the pressure. However, the pump button will continue working at the same speed. In the case of a conventional pumping system with a butterfly valve to regulate the flow compared to a pumping system with a variator to regulate the flow, the final efficiencies of $31 \%$ and $72 \%$, respectively, as shown in Table 1.

Table 1: Comparison of two pumping systems with and without variable speed drive. Source of data: Prepared by the authors based on data from (UPME, CORPOEMA, 2014).

\begin{tabular}{|c|c|c|c|c|c|c|c|c|}
\hline \multirow{2}{*}{\multicolumn{2}{|c|}{$\begin{array}{c}\text { System/ } \\
\text { Energy } \\
\text { Input }\end{array}$}} & \multicolumn{6}{|c|}{ Efficiency \% } & \multirow{2}{*}{$\begin{array}{l}\text { Energy } \\
\text { Output }\end{array}$} \\
\hline & & \multirow[t]{2}{*}{$\begin{array}{c}\text { Motor } \\
\\
-\end{array}$} & \multirow{2}{*}{$\begin{array}{c}\text { Coupling } \\
\\
90\end{array}$} & \multirow{2}{*}{$\begin{array}{c}\text { Pump } \\
\\
98 \\
\end{array}$} & \multirow{2}{*}{$\begin{array}{c}\text { Thorttle } \\
\\
77 \\
\end{array}$} & \multirow{2}{*}{$\begin{array}{c}\text { Pipe } \\
\\
66\end{array}$} & \multirow{2}{*}{$\begin{array}{r} \\
69 \\
\end{array}$} & \\
\hline 1 & 100 & & & & & & & 31 \\
\hline 2 & 43 & 96 & 95 & 99 & 88 & - & 90 & 31 \\
\hline
\end{tabular}

Asynchronous motors have regulations in industrialized countries that created a normative classification with which the consumer is sought to have a broader knowledge of the motor they wish to acquire. According to the International Electrotechnical Commission (IEC in English), they are classified with the initials "IE "Of international efficiency and in increasing order such as IE1, IE2, and IE3, the latter being the most efficient. And according to the classification of the European Committee of Manufacturers of Electrical Machines and Power Electronics (CEMEP in English) as EFF3, EFF2, and EFF1, the latter being the most efficient (UPME, CORPOEMA, 2014) (Saidur, 2010).

In the combustion of the fuels used in the boilers, part of the calorific value of the boiler is used, and another part is wasted in the exhaust gases. The economizer is an element that makes it possible to take advantage of the residual heat from the exhaust gases that are thrown away from the environment with which the inlet water is heated. This makes the efficiency of the boiler increase by $2.5 \%$ to $4 \%$ depending on the number of tubes, the addition of fins to increase the transfer area, and the allowed pressure drops and mostly from the inlet temperature of the boiler feedwater. For every $40^{\circ} \mathrm{F}$ reduction in the temperature of the exhaust gases, the efficiency of the boiler is increased by $1 \%$.

\subsection{STATUS IN COLOMBIA}

The productive industrial sector of beverages in Colombia consumes $91.7 \%$ of its thermal energy in natural gas, $0.1 \%$ in Motor Fuel Oil (ACPM in Spanish), and $8.2 \%$ in other fuels. In general, this beverage sector has a specific average consumption in electrical energy of 9.78 $\mathrm{kWh} / \mathrm{HL}$ and a specific consumption in average thermal energy of $12.56 \mathrm{kWh} / \mathrm{HL}$, which gives a relationship between thermal energy and 1.52 average electric power.

Figure 1 shows the sector has a consumption of electrical energy for the motive force of 32,015 $\mathrm{MWh}$, for refrigeration $14,514 \mathrm{MWh}$, the latter includes all the equipment of the cold chain such 
as compressors, fans of vapor compression refrigeration cycles, chillers, and cooling towers. In compressed air, the sector consumes 7,187 MWh. In lighting, it consumes 3,783 MWh, and in air conditioning, it consumes 3,013 MWh.
Office equipment is also quantifiable within the sector's electricity consumption, which is 1,822 MWh. The beverage sector also uses electric energy for direct heating, which is $685 \mathrm{MWh}$.

Figure 1: Electric power consumption in the ISIC sector. Source of data: Prepared by the authors based on data from (UPME, Colciencias, Incombustion, 2014).

Electric power consumption in the

ISIC sector

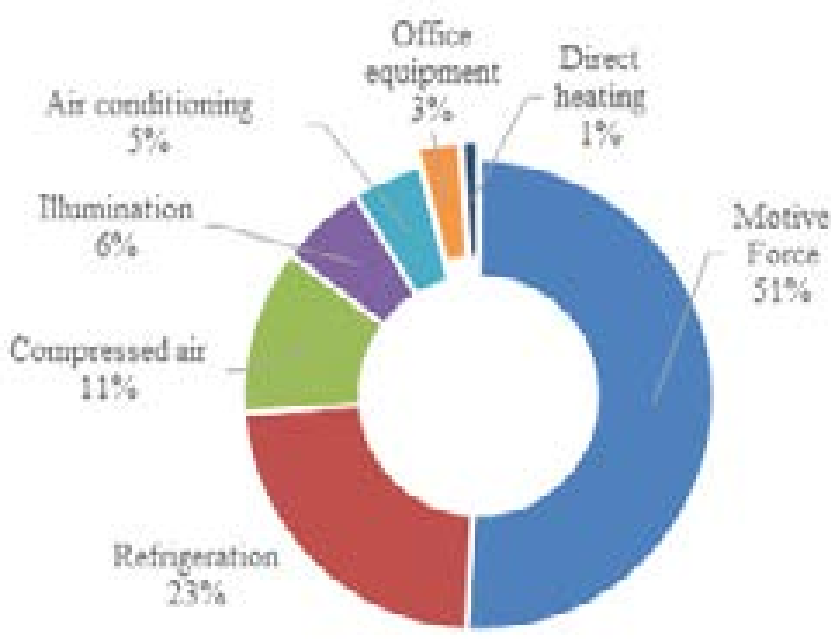

The use of thermal energy in the beverage sector for the production of steam in indirect heating derived from combustion is 222,783 MWh. For the production of steam, fire tube type boilers are used, of which $94 \%$ are fueled by natural gas with a power of $7,505 \mathrm{bhp}$ and $6 \%$ by Biogas with a power of $800 \mathrm{bhp}$. In some industries, the project is to use boilers that run on biogas produced in wastewater treatment plants. The beverage sector registers $90 \%$ of the use of boilers that are between 23 and 14 years old.

The control of the efficiency in the boilers of the sector is null, as is the use of high-efficiency burners with NOx control. A comparison is made that reveals the potential for savings by recovering heat in the exhaust gases, taking into account that for every $22^{\circ} \mathrm{C}$ of temperature reduction in the exhaust gases, the efficiency of the boiler increases by $1 \%$.
Table 2: Efficiency gained with heat recovery. Source of data: Prepared by the authors based on data from (UPME, Colciencias, Incombustion, 2014).

\begin{tabular}{|c|c|c|}
\hline $\begin{array}{c}\Delta \text { temperature } \\
\text { (without heat } \\
\text { recovery - with } \\
\text { heat recovery) }\end{array}$ & $\begin{array}{c}\Delta \text { temperature } \\
\text { (without heat } \\
\text { recovery - } \\
\text { with heat } \\
\text { recovery) }\end{array}$ & $\begin{array}{c}\text { Gained } \\
\text { efficiency }\end{array}$ \\
\hline $\begin{array}{c}\text { Maximum } \\
\text { temperature }\end{array}$ & -155 & $-7.045 \%$ \\
\hline $\begin{array}{c}\text { Minimum } \\
\text { temperature }\end{array}$ & 37 & $1.682 \%$ \\
\hline
\end{tabular}

It can be seen in Table 2 that with the installation of a heat recovery unit, the efficiency of the boiler can be increased and that it works. It acquires this efficiency at minimum temperatures, making the energy-saving greater by having to use the boiler at temperatures below average. 
The indirect heating generated by the boilers in the sector is intended to produce steam for heating water for washing containers, direct steam for washing containers, and heating water for finishing.

In the use of motive force for the sector, $24.36 \%$ of the engines are $0.25 \mathrm{hp}, 13 \%$ are $40 \mathrm{hp}$, and $53 \%$ of the engines have powers between $0.25 \mathrm{hp}$ and $40 \mathrm{hp}$. Engines with $40 \mathrm{hp}$ power consume $75 \%$ of the energy used for the motive force. Figure 1 shows the great use of electric motors, and they represent the highest energy consumption. This represents a great potential for energy saving since the motors in the sector have negative aspects in terms of energy efficiency. Most of these motors are asynchronous type AC motors with low efficiency. Only $0.8 \%$ of the sample are high-efficiency motors. In addition, standard efficiency electric motors have an average life of 20 years, and some motors in the sector have already exceeded this age. According to (Bortoni et al., 2013), it is estimated that an electric motor loses 4 efficiency units throughout its useful life due to age. Another important aspect is the load factor; the average of the motors used in the sector has a load factor of $43 \%$. According to the literature, it is known that electric motors have their highest efficiency with a load factor above $50 \%$ and $100 \%$. This varies depending on each motor. On average, for the efficiency of $100 \%$, it is a load factor of $75 \%$ (Office of Energy Efficiency and Renewable Energy, s.f.).

In the lighting area, the sector presents different types of lamps, such as T12, T8, and T5 fluorescent lamps, metal halide, mercury vapor, sodium vapor, incandescent, and LEDs. In the case of fluorescent lamps designated with the nomenclatures $T 12, T 8$, and $T 5$, the $T 8$ has a greater share in the industry of the sector shown in Figure 2. Despite the fact that this group of fluorescent lamps is more efficient in energy consumption per watt than incandescent, metal halide, and mercury vapor lamps, there are also significant differences between these fluorescent lamps in terms of efficiency and energy-saving due to light capacity. T12 lamps are already old technology. The lamp with the highest efficiency of the 3 is the T5. Since it requires less mercury and $45 \%$ less energy for a higher light intensity than the T12, it has an electronic ballast, it does not lose light intensity as its predecessor, and it occupies less space. However, it is the lamp with almost no use in the industry.

Figure 2: Energy consumption in lighting by type of luminaire in the ISIC sector. Source of data: Prepared by the authors based on data from (UPME, Colciencias, Incombustion, 2014).

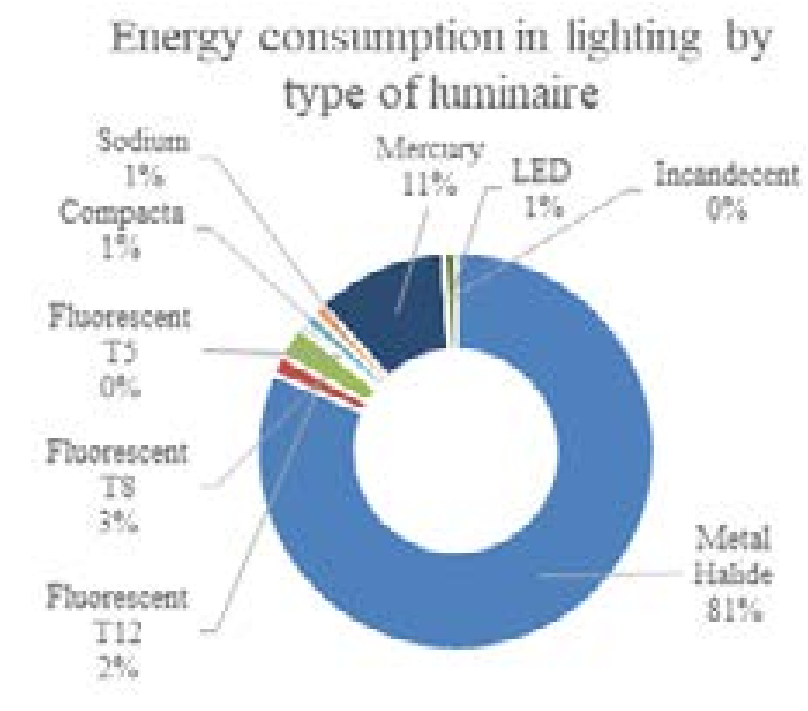


In Figure 3, it seemed that halide lamps have high participation being $55 \%$ of the total, followed by mercury vapor lamps with a participation of $13 \%$. This shows that there is still a permanence of old and inefficient technologies but a great potential for savings. It can also be seen that within the group of fluorescent lamps, T8s have a $22 \%$ share of the total. However, these lamps can be replaced by newer and more efficient technologies. The participation of led lamps is almost nil in the sector.

Figure 3: Share of luminaire types in quantity and consumption in the ISIC sector. Source of data: Prepared by the authors based on data from (UPME, Colciencias, Incombustion, 2014).

\section{Share of luminaire types in quantity and consumption}

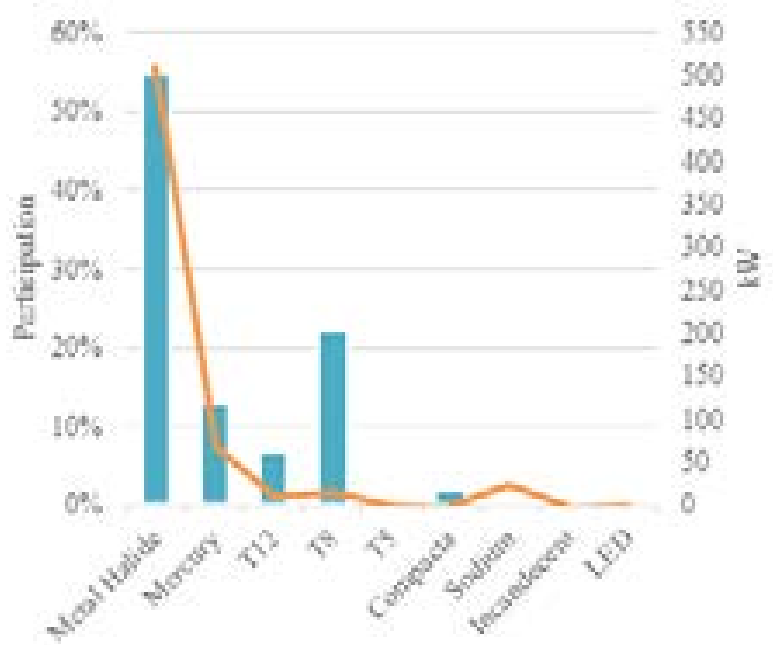

The potential for saving electrical energy for lighting is up to $50 \%$. Although there are internal programs in companies to improve the efficiency of energy consumption in lighting, there is still strong opposition to the use of LED lamps and LEDs powered by solar panels due to their high cost compared to other lamps with less efficient technologies.

Figure 4: Share of compressor types and installed power in the ISIC sector 11. Source of data:

Prepared by the authors based on data from (UPME, Colciencias, Incombustion, 2014).

\section{Share of compressor types and installed power}

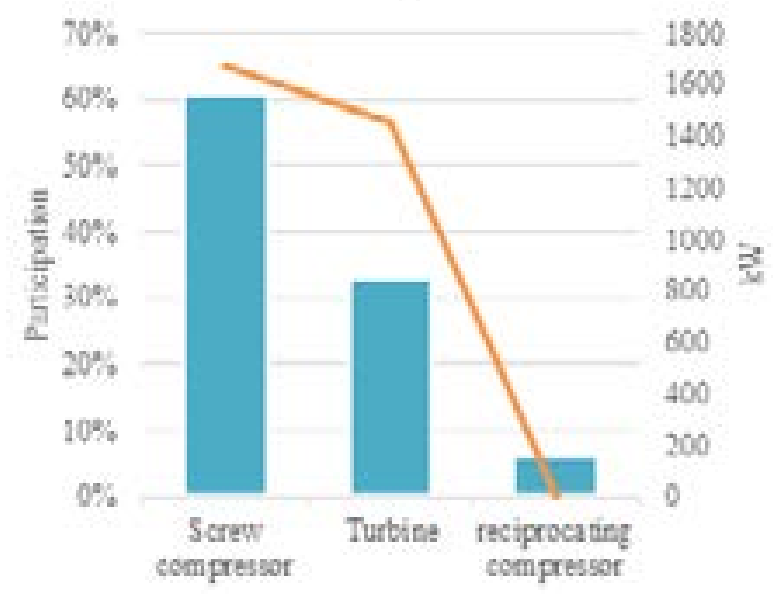


In the sector, the use of compressed air is used to control or activate machinery for the production process. In Figure 4, it can be seen that the types of compressors with the highest participation are screw compressors with $61 \%$ of the total and consumption of $1,674 \mathrm{~kW}$, followed by turbine types with $33 \%$ of the total and a consumption of $46 \%$.

\section{CONCLUSIONS}

The use of high-efficiency electric motors has advantages over normal motors such as lowering operating costs, requires fewer maintenance costs, and longer useful life. This group of characteristics makes high-efficiency motors a good option to reduce the consumption of electrical energy. However, its cost does not seem, and the long-term investment must be analyzed, taking into account the increasing price of energy and the advantages of reducing consumption due to greater efficiency and lower spending on operating and maintenance costs. The return on investment can be seen in approximately 11 months, compared to an average useful life of 20 years.

Metal halide lamps have a shorter lifespan of up to 25,000 hours, and fluorescent lamps have a useful life of about 100,000 hours. That is, metal halide lamps have a useful life of 75,000 hours less than fluorescent lamps. During service, the fluorescent lamp produces an energy saving of $21,250 \mathrm{kWh}$ and an emission reduction of 5.8 tCO2 compared to the metal halide lamp. The profitability of this option is $6.5 \%$ per month. This shows that significant savings can be achieved that have an economic saving for the company and an increase in energy efficiency, in addition to the consequent decrease in pollution.

In Colombia, efforts are being made to raise awareness in the industrial sector for the use of more intensive actions to improve energy efficiency with energy characterization programs and studies carried out by the government through the UPME. However, policies are lacking mandatory that promote the implementation of these programs, such as the replacement of low-efficiency electric motors and long hours of use, also adopting international characterization standards for the efficiency of electric motors is a good option as has been done in industries of countries more developed. Renewing the boiler park that has already passed its useful life with high-efficiency boilers and that have heat recovery devices is another of the actions that could significantly reduce energy consumption, in addition to stronger replacement policies being carried out through stronger policies of low-efficiency lamps.

In general, the different industrial sectors have the same drawbacks in terms of energy uses, since each sector makes use of the energy available in the country in the same way, but with differences in the amount they use, except for certain particularities of each sector. This is why the regulations and advances that are applied in one sector serve the rest of the industry to a greater or lesser extent.

In Colombia, the programs developed by entities in charge of energy management such as CREG, UPME, or the Ministry of Mines and Energy are in the stage of creating awareness of energy efficiency, and their programs and regulations are mostly based on the promotion of efficient use of energy and voluntary energy saving. According to this, there are no resolutions or decrees that seek the penalty or fine for the use of low-efficiency equipment in the industry or equipment that, according to updated technical studies with international standards, determines a state of operation outside the years of useful life.

The beverage industry in Colombia requires more in-depth work on the importance of creating a history of the installed motor park and control of its power, efficiency, and load 
factor data since both small and large Industries lack such records.

\section{REFERENCES}

Abdelaziz , E., Saidur , R., \& Mekhilef , S. (2011). A review on energy saving strategies in industrial sector. Renewable and Sustainable Energy Reviews, 15, 150168.

Bermeo, M., \& Ocampo-Martinez, C. (2019). Energy efficiency improvement through MPC-based peripherals management for an industrial process test-bench. IFAC-PapersOnLine, 52, 648-653.

Bortoni, E., Nogueria, L., Cardoso, R., Haddad, J., Souza, E., \& Yamachita, R. (2013). Assessment of the achieved savings from induction motors energy efficiency labeling in Brazil. Energy Conversion and Management, 75, 734-740.

Bunse, K., Vodicka, M., Schönsleben, P., Brülhart , M., \& Ernst , F. (2011). vintegrating energy efficiency performance in production management - gap analysis between industrial needs and scientific literature. Journal of Cleaner Production, 19, 667-679.

Campos I, B., Nieto, N., Del Portillo-Valdes, L., Manzanedo, J., \& Gaztaña, H. (2020). Energy efficiency optimisation in industrial processes: Integral decision support tool. Energy, 191, 116480.

CEPAL, \& GTZ. (2003). Sostenibilidad Energética en America Latina y el Caribe: el aporte de las fuentes renovables. Brasilia., Available from: https://repositorio.cepal. org/handle/11362/2764, [Last accessed on 2020 April 15].
CEPAL, \& GTZ. (2004). Fuentes Renovables de Energía en América Latina y el Caribe: situación y propuestas de politicas. Santiago. Available from: https://www. cepal.org/es/publicaciones/31904fuentes-renovables-energia-americalatina-caribe-situacion-propuestaspoliticas, [Last accessed on 2020 April 15].

Chaichaloempreecha , A., Winyuchakrit , P., \& Limmeechokchai , B. (2017). Assessment of renewable energy and energy efficiency plans in Thailand's industrial sector. Energy Procedia, 138, 841-846.

Chowdhury, J., Hu, Y., Haltas, I., Balta-Ozkan, N., Matthew , G., \& Varga, L. (2018). Reducing industrial energy demand in the UK: A review of energy efficiency technologies and energy saving potential in selected sectors. Renewable and Sustainable Energy Reviews, 94, 1153-1178.

Congreso de la República de Colombia. (2014). Ley 1715 de 2014 Diario Oficial No. 49.150 de 13 de mayo de 2014. Bogotá, Colombia. Available from: http://www. secretariasenado.gov.co/senado/ basedoc/ley_1715_2014.html. [Last accessed on 2020 April 08.]

DANE. (2020, April 14). DANE Información para todos. Available from: dane.gov. co: https://www.dane.gov.co/index. php/sistema-estadistico-nacional-sen/ normas-y-estandares/nomenclaturasy-clasificaciones/clasificaciones/ clasificacion-industrial-internacionaluniforme-de-todas-las-actividadeseconomicas-ciiu. [Last accessed on 2020 April 14]. 
Dindorf , R. (2019). Estimating Potential Energy Savings in Compressed Air Systems. Procedia Engineering, 39, 204-211.

Duflou , J., Sutherland , J., Dornfeld , D., Herrmann , C., Jeswiet , J., Kara , S., . . Kellens, K. (2012). Towards energy and resource efficient manufacturing: $A$ processes and systems approach. CIRP Annals, 12, 587-609.

Fluch, J., Brunner, C., \& Grubbauer, A. (2017). Potential for energy efficiency measures and integration of renewable energy in the European food and beverage industry based on the results of implemented projects. Energy Procedia, 123, 148-155.

Flum, D., Abele, E., \& Reidel, O. (2018). Model-based Planning of Energy Flexible Technical Building Services in Production Plants to Integrate Variable Renewable Energies. Procedia CIRP, 69, 654-659.

Geller, H., Harrington , P., Rosenfeld , A., Tanishima , S., \& Unander , F. (2006). Polices for increasing energy efficiency: Thirty years of experience in OECD countries. Energy Policy, 34, 556-573.

Giacone, E., \& Mancò, S. (2012). Energy efficiency measurement in industrial processes. Energy, 38, 331-345.

Gobierno de Colombia. (1992). Decreto 2119 de 1992 Diario Oficial No. 40.704, del 31 de diciembre de 1992. Bogotá, Colombia. Available from: http://forvm.com.co/ wp-content/uploads/2015/04/Decreto2119-29-12-1992.-MInisterio-de-MInasy-Energia..pdf, [Last accessed on 2020 April 15].

Gobierno de Colombia. (1994). Ley 143 de 1994 Diario Oficial No. 41.434, de 12 de julio de 1994. Bogotá, Colombia. Available from: http://www.secretariasenado.gov. co/senado/basedoc/ley_0143_1994. html, [Last accessed on 2020 April 12].

Gobierno de Colombia. (2001). LEY 697 DE 2001 Diario Oficial No. 44.573, de 05 de octubre de 2001. Bogotá, Colombia.Available from http://www. secretariasenado.gov.co/senado/ basedoc/ley_0697_2001.html, [Last accessed on 2020 April 12].

Gobierno de Colombia. (2008). Resolución 909 Por la cual se establecen las normas y est ándares de emisión admisibles de contaminantes a la atmósfera porfuentes fijas y se dictan otras disposiciones. Ministerio de Ambiente, Vivienda y Desarrollo Territorial, Bogotá, Colombia. Available from: http://www.ideam. gov.co/documents/51310/527650/ Resolucion $+909+d e+2008$. pdf/a 3bcdf0d-f1ee-4871-91b918eac559dbd9. [Last accessed on 2020 April 10].

Gobierno de Colombia. (2013). Decreto 1258 de 2013 Diario Oficial No. 48.824 de 17 de junio de 2013. Bogotá, Colombia.Available from: http://www. secretariasenado.gov.co/senado/ basedoc/decreto_1258_2013.html\#4, [Last accessed on 2020 April 14].

Gobierno de Colombia. (n.d.). cambioclimatico. Available from IDEAM: http://www. cambioclimatico.gov.co/estrategiacolombiana-de-desarrollo-bajo-encarbono, [Last accessed on 2020 April 14]. 
Gobierno Nacional. (2005). Resolución CREG 018

Gestión del flujo de potencia reactiva.

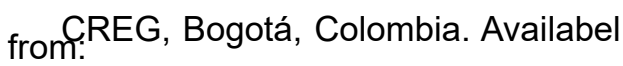
http://apolo.creg.gov.co/Publicac. nsf/1c09d18d2d5ffb5b05256 eee00709c02/8f0d 46ae7d55f6640525785a007a 6b74/\$FILE/D-018\%20 GESTI\%C3\%93N\%20DEL\%20FLUJO

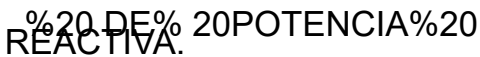

pdf, [Last accessed on 2020 April 15].

Gobierno Nacional. (2016). Resolución 029. CREG, Bogotá, Colombia.Available from: http://apolo.creg.gov.co/Publicac. nsf/1c09d-18d2d5ffb5b05256eee00709 c02/11d218ae3d892c1605257f70004e d535?OpenDocument, [Last accessed on 2020 April 15]

Hoffmann, C., Praß , J., Uhlemann , T., \& Franke, J. (2019). Improving the energy efficiency of industrial drying processes: a computational fluid dynamics approach. Procedia Manufacturing, 33, 422-429.

Knopf , B., Nahmmacher , P., \& Schmid, E. (2015). The European renewable energy target for 2030 - An impact assessment of the electricity sector. Energy Policy, $85,50-60$.

López, A., Krumm , A., Schattenhofer , L., Burandt, T., Montoya, F., Oberländer, N., \& Oei, P.-Y. (2020). Solar PV generation in Colombia - A qualitative and quantitative approach to analyze the potential of solar energy market. Renewable Energy, 148, 1266-1279.
Meyers, S., Schmitt , B., Chester-Jones, M., \& Sturm , B. (2016). Energy efficiency, carbon emissions, and measures towards their improvement in the food and beverage sector for six European countries. Energy, 104, 266-283.

MINMINAS, UPME. (2016). Plan de acción indicativo de eficiencia energética 20172022. Bogotá, Colombia. Available from: https://www1.upme.gov.co/Paginas/ Plan-de-Acci\%C3\%B3n-Indicativode-Eficiencia-Energ\%C3\%A9tica-PAIPROURE-2017---2022.aspx, [Last accessed on 2020 April 10]

NU. CEPAL \& CAF. (2013). Energía: una visión sobre los retos $y$ oportunidades en América Latina y el Caribe. CEPAL; CAF. Available from: https://www.cepal. org/es/publicaciones/1505-energiavision-retos-oportunidades-americalatina-caribe, [Last accessed on 2020 April 10].

Office of Energy Efficiency and Renewable Energy. (n.d.). Determining Electroc Motor Load and Efficiency. Available from: https://www.energy.gov: https://www.energy.gov/sites/prod/ files/2014/04/f15/10097517.pdf, [Last accessed on 2020 April 08]

Ogunjuyigbe , A., Ayodele , T., \& Ogunmuyiwa , S. (2015). Improving electrical energy utilization in some selected Nigerian food and beverage industries. Sustainable Energy Technologies and Assessments, 12, 38-45.

PRIAS, O. (2010). Programa de uso racional y eficiente de energía y fuentes no convencionales (PROURE). Bogotá D.C. [Last accessed on 2020 April 05]. 
Pupo-Roncallo, O., Campillo, J., Ingham, D., Hughes, K., \& Pourkashanian, M. (2020). Renewable energy production and demand dataset for the energy system of Colombia. Data in Brief, 28, 105084. doi:10.1016/J.DIB.2019.105084

Rissman , J., Bataille , C., Masanet, E., Aden , N., Morrow, W., Zhou, N., ... Heeren, N. (2020). Technologies and policies to decarbonize global industry: Review and assessment of mitigation drivers through 2070. Applied Energy, 266, 114848.

Saidur, R. (2010). A review on electrical motors energy use and energy savings. Renewable and Sustainable Energy Reviews, 14, 877-898.

Santana, P., \& Bajay, S. (2016). New approaches for improving energy efficiency in the Brazilian industry. Energy Reports, 2, 62-66.

Solaun, k., \& Cerdá, E. (2019). Climate change impacts on renewable energy generation. A review of quantitative projections. Renewable and Sustainable Energy Reviews, 116, 109415.

Tanaka, K. (2011). Review of policies and measures for energy efficiency in industry sector. Energy Policy, 39, 65326550.

Thollander , P., \& Ottosson, M. (2010). Energy management practices in Swedish energy-intensive industries. Journal of Cleaner Production, 18(12), 1125-1133.

Tzimas , E., Georgakaki, A., \& Peteves, S. (2009). Reducing CO2 emissions from the European power generation sectorScenarios to 2050. Energy Procedia, 1, 4007-4013.
U.S. Energy Information Administration. (2019). International Energy Outlook 2019 with projections to 2050. Office of Energy Analysis, U.S. Department of Energy, Washington, DC. Available from: https:// www.eia.gov/outlooks/ieo/pdf/ieo2019. pdf, [Last accessed on 2020 April 10].

United Nations. (2008). International Standard Industrial Classification of All Economic Activities. Department of Economic and Social Affairs, Statistics Division. UNITED NATIONS PUBLICATION. Available from: https://unstats. un.org/unsd/publication/seriesm/ seriesm_4rev4e.pdf, [Last accessed on 2020 April 10].

UPME. (2017). BECO. Available from: https:// www1.upme.gov.co/InformacionCifras/ Paginas/BECOCONSULTA.aspx, [Last accessed on 2020 April 14].

UPME. (2018). Resolución 000703 de 2018. Available from: https://www1.upme. gov.co/Paginas/incentivos-FNCE.aspx, [Last accessed on 2020 April 14].

UPME, Colciencias, Incombustion. (2014). Determinación del potencial de reducción del consumo energético en los subsectores manufactureros códigos CIIU 10 a 18 en Colombia. Medellín. Available from: https://www1.upme.gov. co/DemandaEnergetica/INFORME_III_ Caracterizacion_energetica_VerPub. pdf, [Last accessed on 2020 April 12].

UPME, CORPOEMA. (2014). Determinación y priorización de alternativas de eficiencia energética para los subsectores manufactureros códigos CIIU 19 a 31 en Colombia a partirde la caracterización del consumo energético para sus diferentes procesos, usos y equipos de uso final. Bogotá.Available from: http://www1. 
upme.gov.co/DemandaEnergetica/ DeterminacionEficiencia/Informe Final_Volumen_1.pdf, [Last accessed on 2020 April 15].

WEC. (2011). Policies for the future: 2011 Assessment of country energy and climate policies. London. Available from: https://www.worldenergy.org/ publications, [Last accessed on 2020 April 15].

Wongsapai , W., Fongsamootr , T., \& Chaichana , C. (2017). Evaluation of Energy Saving Potential for Small and Medium Enterprises (SMEs) in Thailand. Energy Procedia, 228-232.

Zapata, S., Castaneda, M., Jimenez, M., Aristizabal, A., Franco, C., \& Dyner, I. (2018). Long-term effects of $100 \%$ renewable generation on the Colombian power market. Sustainable Energy Technologies and Assessments, 30, 183-191.

Zhou, S., Wang, Y., \& Ou, X. (2018). Peak energy consumption and $\mathrm{CO} 2$ emissions in China's industrial sector. Energy Strategy Reviews, 20, 113-123. 